\title{
Competitive spawning success and fertility of triploid male Atlantic cod Gadus morhua
}

\author{
Nathaniel J. Feindel ${ }^{1,2, *}$, Tillmann J. Benfey ${ }^{1}$, Edward A. Trippel ${ }^{2}$ \\ ${ }^{1}$ Department of Biology, University of New Brunswick, PO Box 4400, Fredericton, New Brunswick E3B 5A3, Canada \\ ${ }^{2}$ Fisheries and Oceans Canada, St. Andrews Biological Station, 531 Brandy Cove Road, St. Andrews, New Brunswick E5B 2L9, \\ Canada
}

\begin{abstract}
Farmed Atlantic cod Gadus morhua have been hypothesized to pose a risk to the natural environment through escape of fish or release of their gametes from sea cages. The use of sterile triploids has been suggested as a way to prevent spawning of farmed fish, whether escaped from their cages or still contained within them. This laboratory study examined the reproductive potential of triploid male Atlantic cod, both in vivo and in vitro. We demonstrated that triploid males in competitive, size-matched mating with diploid males were successful at siring young. Spermatozoa produced by triploid males were larger than those of diploids, but did not differ in swimming velocity or ability to fertilize eggs. Hatch and larval survival rates, however, were reduced for progeny of triploid males. These diagnostic characteristics of aneuploidy suggest that although farmed triploid male cod may compete successfully with wild diploids for spawning access to wild females, their offspring will not survive.
\end{abstract}

KEY WORDS: Triploidy · Mating · Fertilization · Spermatozoa · Embryo · Larval survivorship • Atlantic cod · Escapee

Resale or republication not permitted without written consent of the publisher

\section{INTRODUCTION}

Atlantic cod Gadus morhua is a candidate species for diversifying marine finfish aquaculture in North Atlantic countries which have historically focused on Atlantic salmon Salmo salar farming. Preliminary trials have identified sexual maturation of farmed cod as a constraint to the expansion of commercial culture. Cod spawning within sea cages or their escape from sea cages and spawning in the wild could have negative impacts on wild cod stocks (Bekkevold et al. 2006, Jørstad et al. 2008), some of which have been listed as endangered by the Committee on the Status of Endangered Wildlife in Canada. The development of cod aquaculture can benefit from long-standing, parallel concerns with Atlantic salmon escapees. Farmed salmon have been documented to spawn with wild salmon (Webb et al. 1991, Carr et al. 1997, Hindar et al. 2006), resulting in the genetic introgression of farmed traits into wild gene pools (Crozier 1993) and potentially lowering the overall fitness of wild stocks (Utter
1998, Youngson et al. 2001, Hutchings \& Fraser 2008). Compared to salmon, cod are more prone to escape from sea cages based on reports of biting at holes in nets to enlarge them to facilitate their escape (Moe et al. 2007, 2009), though other factors also contribute to fish escapes including marine accidents, creation of holes in nets by predators and damage to sea cages from storms. Unlike salmon, cod also spawn within sea cages, resulting in embryos being released into the natural environment (Jørstad et al. 2008). Pre-harvest sexual maturation is also of direct concern to the aquaculture industry, as mature fish have lower fillet quality and, hence, lower economic value (Taranger et al. 2010).

Triploidy induction suppresses gonadal development in many fish species (Piferrer et al. 2009) and could potentially solve the problems associated with early puberty and cage spawning of Atlantic cod. Theoretically, triploidy leads to higher growth rates, as a result of a greater amount of energy being directed towards somatic growth as these animals bypass the expense of 
gonadal growth and development (Cal et al. 2006, Piferrer et al. 2009). Disruption of gonadal development occurs in triploids when their germ cells enter meiosis I because the presence of a third set of chromosomes interferes with the normal pairing of homologous chromosomes in meiotic prophase, inhibiting further gamete development. The effect of triploidy on gonadal suppression tends to be greater for females than for males, and in a number of species triploid males develop to a spawning state and produce functional spermatozoa (Benfey 1999, Piferrer et al. 2009), as has been demonstrated in cod (Trippel et al. 2008, Peruzzi et al. 2009). However, any offspring sired by triploid males will likely be aneuploid and therefore not survive past embryonic or larval stages (Benfey 1999, Piferrer et al. 2009). Triploidy induction can thus act as a control for the genetic introgression of cultured genes into wild gene pools.

Through a combination of in vivo and in vitro experiments, the present study tested the hypothesis that triploid male Atlantic cod cannot compete effectively with diploid males to sire offspring. It was predicted that (1) a triploid male would sire fewer offspring than a diploid male when placed in a spawning tank with an ovulated diploid female, (2) the spermatozoa from triploid males would have poorer motility and be less successful at fertilizing eggs in vitro than those from diploids and (3) triploid-sired offspring would have reduced embryonic and larval survival.

\section{MATERIALS AND METHODS}

Study organisms. The Atlantic cod used in these experiments were maintained at the St. Andrews Biological Station (Fisheries and Oceans Canada, St. Andrews, New Brunswick) and were offspring of wild broodstock (85 to $100 \mathrm{~cm}$ in length, 6 to $15 \mathrm{~kg}$ ) captured from the Bay of Fundy (Northwest Atlantic Fisheries Organization, Division 4X). Experimental animals were produced on 9 March 2005 from 2 females and 2 males. For each full-sib family, an egg batch was manually stripped from a female, fertilized with milt from a male and immediately divided into 2 groups: one retained as diploid controls and the other used to generate triploids by hydrostatic pressure treatment (5 $\min$ at $58600 \mathrm{kPa}$, beginning $180^{\circ} \mathrm{Cmin}$ postfertilization; for details see Trippel et al. 2008) using a commercial pressurizing system (TRC-HPCTM; TRC Hydraulics). Diploids and triploids of each of the 2 families were reared separately to the juvenile stage, PITtagged, and then combined and maintained in two 70001 circular tanks and fed a marine grower diet (EWOS Canada). Different wild broodstock, also from the Bay of Fundy, were used to generate the diploid populations from which females were obtained for the spawning experiments described below. These fish were maintained in a separate tank, but treated in the same manner in relation to husbandry practices.

Ploidy verification. All triploids and diploids used in these experiments were verified as being of the correct ploidy by flow-cytometric measurement of erythrocyte DNA content (Allen 1983). For each fish, a $5 \mu \mathrm{l}$ sample of whole blood was added to $1 \mathrm{ml}$ of propidium iodide (50 $\mathrm{mg} \mathrm{l}^{-1}$ in $0.1 \%$ sodium citrate). Individual samples were mixed on a vortex mixer (Fisher Scientific) for $5 \mathrm{~s}$ and refrigerated overnight (at $6^{\circ} \mathrm{C}$ ). The following day $(\approx 15 \mathrm{~h}$ later $)$, the samples were mixed, $100 \mu \mathrm{l}$ of dimethylsulfoxide was added, they were mixed again and they were then stored at $-20^{\circ} \mathrm{C}$ until later analysis at the Dr. Everett Chalmers Hospital (Fredericton, New Brunswick). Similarly prepared samples from a single diploid brook charr Salvelinus fontinalis were used as a standard.

In vivo competitive spawning experiment. On 24 January 2008, 18 cod were selected from the holding tanks and sorted to form 6 trios, each comprised of a diploid male, a triploid male and a diploid female, and transferred to 6 circular tanks $\left(3 \mathrm{~m}^{3} ; 1.83 \mathrm{~m}\right.$ diameter and $1.17 \mathrm{~m}$ deep) each equipped with a surface egg collector (Thorsen et al. 2003). Water temperature ranged from 5 to $8^{\circ} \mathrm{C}$ over the experimental period ending 2 April 2008 and no significant difference was noted in water temperature among tanks (ANOVA, p > 0.05). Upon transfer, a fin clip was collected from each fish and preserved in $95 \%$ ethanol. Paired males were full-sibs and were matched by weight ( $\left.\mathrm{W}_{i} \pm 24.0 \mathrm{~g}\right)$, length ( $\mathrm{L}_{\text {; }}$ $\pm 2.1 \mathrm{~cm})$ and Fulton's condition factor $\left(K=\left[\mathrm{WL}^{-3}\right] \times 100\right.$; \pm 0.1 ) to minimize genetic, size- or shape-related factors affecting dominance (males within a tank did not differ by more than $11 \%$ for each physical body trait) (Table 1 ). Males within a trio came from different holding tanks to avoid prior exposure to each other. Females were from a separate family to avoid inbreeding and were paired with males of similar body length (within $13 \%$ by length) (Rakitin et al. 2001). Egg collectors were checked twice daily for the occurrence of spawning and a minimum of 20 embryos were randomly sampled from each spawning event and stored in 95\% ethanol for subsequent genetic analysis of parentage.

Adult fin clips and sampled embryos were genotyped using 6 previously published microsatellite markers (Gmo8, Gmo19 and Gmo37, Miller et al. 2000; Tch5 and Tch11, O'Reilly et al. 2000; and PGmo38, Jakobsdóttir et al. 2006). DNA isolation and genotyping were conducted by the Research and Productivity Council of New Brunswick (Fredericton, New Brunswick). Parentage (diploid or triploid) of embryos was assigned visually by aligning genotypes of parents and progeny in Microsoft Excel. 
Table 1. Gadus morhua. Trios of cod used for the in vivo competitive spawning experiment. Diploid males (2nM) and triploid males (3nM) were siblings, and were size-matched within tanks based on their body length, weight and Fulton's condition factor $(K)$. Diploid females $(2 \mathrm{nF})$ were from a separate family

\begin{tabular}{|c|c|c|c|c|c|}
\hline Trio & Fish & Family & Length $(\mathrm{cm})$ & Weight (kg) & $K$ \\
\hline \multirow[t]{3}{*}{1} & $2 \mathrm{nM}$ & 1 & 47.5 & 1.55 & 1.45 \\
\hline & $3 \mathrm{nM}$ & 1 & 48.3 & 1.545 & 1.37 \\
\hline & $2 \mathrm{nF}$ & 3 & 47.5 & 1.83 & 1.71 \\
\hline \multirow[t]{3}{*}{2} & $2 \mathrm{nM}$ & 2 & 44.5 & 1.19 & 1.35 \\
\hline & $3 \mathrm{nM}$ & 2 & 46 & 1.235 & 1.27 \\
\hline & $2 \mathrm{nF}$ & 4 & 47.2 & 1.65 & 1.57 \\
\hline \multirow[t]{3}{*}{3} & $2 \mathrm{nM}$ & 2 & 48.8 & 1.405 & 1.21 \\
\hline & $3 \mathrm{nM}$ & 2 & 49 & 1.395 & 1.19 \\
\hline & $2 \mathrm{nF}$ & 5 & 48.5 & 1.455 & 1.27 \\
\hline \multirow[t]{3}{*}{4} & $2 \mathrm{nM}$ & 1 & 47.8 & 1.72 & 1.57 \\
\hline & $3 \mathrm{nM}$ & 1 & 48.2 & 1.685 & 1.5 \\
\hline & $2 n F$ & 4 & 49.3 & 1.89 & 1.58 \\
\hline \multirow[t]{3}{*}{5} & $2 \mathrm{nM}$ & 2 & 55.2 & 2.285 & 1.36 \\
\hline & $3 \mathrm{nM}$ & 2 & 53.1 & 2.045 & 1.37 \\
\hline & $2 \mathrm{nF}$ & 7 & 52.3 & 2.045 & 1.43 \\
\hline \multirow[t]{3}{*}{6} & $2 \mathrm{nM}$ & 2 & 51 & 1.57 & 1.18 \\
\hline & $3 \mathrm{nM}$ & 2 & 51 & 1.69 & 1.27 \\
\hline & $2 \mathrm{nF}$ & 7 & 53.6 & 2.68 & 1.74 \\
\hline
\end{tabular}

Data were analyzed using Minitab Statistical Software (v. 15, LEAD Technologies) and were represented by percentages of eggs fertilized by the diploid and triploid male for each spawning event per tank. Eggs that were opaque, ruptured or not fully hydrated were excluded from the analysis. A log-likelihood goodness of fit $G$-test was used to determine whether there was a significant difference between the proportions of embryos sired by each male per batch. Yates correction was applied in each calculation per batch of sired embryos ( $\mathrm{df}=1$ for all tests) (Sokal \& Rohlf 1995). To determine whether the proportions of embryos sired by diploids and triploids were homogenous among batches within a tank, a heterogeneity G-test was applied to trios with more than one batch produced over the duration of the mate competition experiment.

In vitro fertilization, hatch and larval survival rates. To compare fertilization rates, gametes were stripped from diploid females, diploid males and triploid males and procedures followed to conduct fertilization trials at a ratio of 100000 spermatozoa to 1 egg (Butts et al. 2009), with $\sim 300$ eggs per replicate. Individual ovulated females were anaesthetized using tricaine methanesulfonate (76 mg $\mathrm{l}^{-1}$, Aqualife TMS, Syndel Laboratories), the external genital region wiped dry and pressure applied to the abdomen to express eggs which were collected in 31 plastic pitchers and immediately stored in a $6^{\circ} \mathrm{C}$ refrigerated room. The number of eggs per ml of each female was estimated by counting eggs in each of 3 replicate $200 \mu \mathrm{l}$ samples per female and used to estimate the volume required to obtain 300 eggs for subsequent fertilization trials specific to a female. Milt from the 2 males used in the in vitro fertilization trial with a female was then collected and stored in a similar manner as the eggs; 3 milt samples from each male were centrifuged and values used to determine average spermatocrit (i.e. percentage of milt volume occupied by spermatozoa). The amount of milt needed from each diploid and triploid male for fertilization trials per group of eggs was estimated according to a previously published spermatocritspermatozoa density relationship (Rakitin et al. 1999). No significant difference in number of spermatozoa per ml was found for diploid cod compared to triploids (Peruzzi et al. 2009) and, consequently, no numerical adjustments were made according to ploidy in the present study.

Stripped gametes were stored at $6^{\circ} \mathrm{C}$ for $<1 \mathrm{~h}$ prior to fertilization. In the refrigerated room $\left(6^{\circ} \mathrm{C}\right)$, the eggs from one female were fertilized separately using appropriate volumes of milt (Butts et al. 2009) from 1 diploid and 1 triploid male. Fertilizations were replicated 5 times for each male with an individual female, resulting in 10 trios ( 1 diploid male, 1 triploid male and 1 diploid female) using 10 different females and 20 different males. All crosses were performed between 28 February and 01 April 2008. The eggs of each replicate were incubated in separate $250 \mathrm{ml}$ Pyrex beakers for 12 to $24 \mathrm{~h}$, after which the fertilized, unfertilized and non-viable eggs were enumerated. From these counts, fertilization rates were determined for each male using the same method employed above. Non-viable, unfertilized eggs were removed and the fertilized embryos were maintained in replicate $250 \mathrm{ml}$ Pyrex beakers with $75 \%$ water exchanged daily. Developing embryos were examined daily and any dead embryos removed and enumerated until hatching, enabling the estimation of hatching success for each replicate. On the day of peak hatching (i.e. the day when the highest number of embryos hatched), larvae were enumerated and placed in separate $250 \mathrm{ml}$ Pyrex beakers for each replicate; $75 \%$ daily water exchange was maintained. Daily examination of unfed larvae was made and any dead larvae were removed and enumerated. This continued until all larvae had died.

Comparisons of egg fertilization and hatch success between diploid and triploid males were made using a generalized linear model randomized block ANOVA design with females as the random factor and fertilization and hatch rates as the dependent factors. Residuals were plotted to test for normality and standard deviations were compared to assess homogeneity of variances. Larval survival was compared between 
diploid-sired and triploid-sired offspring using an ANCOVA. As a result of low survival of triploid-sired embryos during embryonic development, unequal densities of larvae were placed in the beakers with triploid-sired offspring having an overall lower number of larvae. Regression analysis showed that larval density did not affect larval survival, so the ANCOVA was executed with larval density as a covariate. As density was not significant in the ANCOVA, it was then dropped and the model re-run as a 1-way ANOVA to assess any differences between diploidsired and triploid-sired larval survival. Data for all larvae were then pooled within a ploidy and their arithmetic means used to represent the average day to $100 \%$ mortality for unfed diploid-sired and triploidsired offspring (Probst et al. 2006).

Spermatozoan morphology. Milt samples from diploid $(n=7)$ and triploid $(n=7)$ cod were obtained by applying slight pressure to the abdomen and collecting milt into $50 \mathrm{ml}$ beakers. The initial ejaculate was discarded, to ensure no blood, urine or feces contamination. Immediately after collection, milt samples were covered with Parafilm, kept on ice and then transferred to a $6^{\circ} \mathrm{C}$ refrigerator. For each male, $10 \mu \mathrm{l}$ of milt was then added to $1 \mathrm{ml}$ of a 1:1 mixture of seawater and $3 \%$ sodium citrate (Remel). The solution was then mixed for $30 \mathrm{~s}$ to ensure a homogeneous solution. A $5 \mu \mathrm{l}$ aliquot of the milt mixture was smeared over the length of a labelled microscope slide. Slides were allowed to dry for $\sim 10 \mathrm{~s}$ after smearing and then stained using Hemacolor ${ }^{\circledR}$ (EMD Chemicals; see Tuset et al. 2008 for details). Slides were allowed to air dry and then permanently sealed with Eukitt mounting medium (Kindler \& Co.) under a cover slip $(22 \times 40 \mathrm{~mm})$.

For morphological analyses, images of spermatozoan heads were recorded using Image Pro Plus imaging software (Media Cybernetics), a Leica DMLB microscope (Leica) and a $100 \times$ oil immersion objective. Images were converted to an 8-bit gray scale to facilitate the measurements of spermatozoan morphological parameters through ImageJ v. 1.41o (National Institutes of Health) analysis software. A macro plugin (developed by R. M. Rideout and modified by I. A. E. Butts; see also Butts et al. 2010) was created in ImageJ with set parameters to obtain area $\left(\mu \mathrm{m}^{2}\right)$, perimeter $(\mu \mathrm{m})$, length $(\mu \mathrm{m})$ and width $(\mu \mathrm{m})$ measurements of each spermatozoon. Shape indices such as elongation, $(\mathrm{L}-\mathrm{W})(\mathrm{L}+\mathrm{W})^{-1}$, and ellipticity, $\mathrm{LW}^{-1}$, were also calculated. Measurements of 100 spermatozoa were conducted for each male. For each parameter measured, a 2 sample $t$-test was performed to test for significant differences between diploids and triploids. Assumptions were assessed for each parameter and all data were found to be normally distributed with homogenous variances.
Spermatozoan motility. Milt from 13 cod of each ploidy was used to assess spermatozoan track velocity, also referred to as curvilinear velocity (VCL). Milt was collected in the same manner as described above, with milt from one male collected and VCLs recorded prior to collection of milt from the next male. Spermatozoan motility was assessed using a 2-step activation procedure (Rouxel et al. 2008). Diluted, activated spermatozoa were placed in a 10-well multitest glass slide (MP Biomedicals) and covered with a glass coverslip. Spermatozoan motility was then assessed at 20 and $40 \mathrm{~s}$ post-activation using Integrated Semen Analysis Software (ISAS; Proiser R+D) image analysis software. An ISAS compound microscope with a $40 \times$ negative phase objective and a Basler A312Fc camera (Basler Vision Technologies) were used to capture images of motile spermatozoa at the specified post-activation times. Frames were then manually inspected to ensure that uninterrupted tracks of spermatozoa were analyzed with no interference due to foreign particles or spermatozoa crossing paths resulting in altered tracks which would result in false calculations of VCLs. A repeated measures ANOVA was applied to test whether there was a significant difference in VCLs between diploid and triploid spermatozoa at 20 and 40 s postactivation. Data were normally distributed and had homogenous variances at both post-activation times.

\section{RESULTS}

\section{In vivo competitive spawning experiment}

Log-likelihood goodness of fit G-tests performed on individual batches within tanks revealed significant differences in proportions of larvae sired by each male for all batches ( $\mathrm{p}<0.05)$ (Table 2$)$. Batches were dominated in all tanks by either a diploid or a triploid male, with no 2 males siring an equal proportion of offspring during a single spawning event. Heterogeneity G-tests also revealed significant differences in the proportions of larvae sired by each male over numerous batches in some, but not all, tanks ( $<<0.05)$ (Table 2).

\section{In vitro fertilization, hatch and larval survival rates}

Analysis of the 10 in vitro fertilization trials revealed no significant difference in fertilization success between diploid $(44.1 \pm 9.7 \%$; mean $\pm \mathrm{SE})$ and triploid males $(38.9 \pm 9.3 \%)$ (see Fig. 1 for results from individual crosses). There was, however, a significant difference in hatching success of their offspring $(43.1 \pm 5.6$ and $19.5 \pm$ $4.0 \%$, respectively; $\mathrm{p}<0.05$ ) (see Fig. 2 for hatch success from individual crosses). Regression analysis revealed 


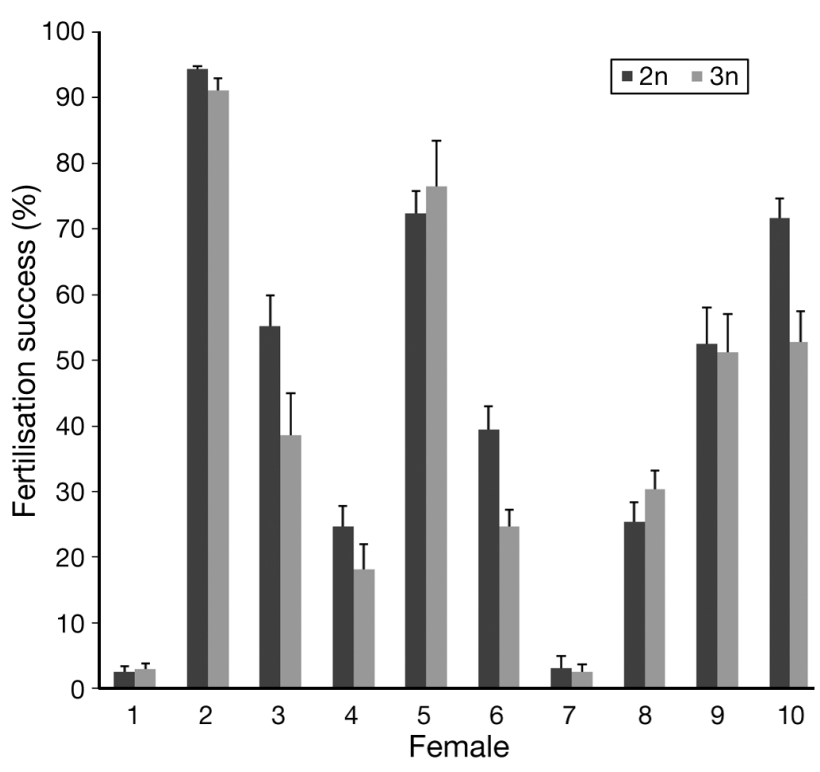

Fig. 1. Gadus morhua. Fertilization success of milt from diploid (2n) and triploid (3n) Atlantic cod using in vitro fertilization trials involving 20 males (matched as siblings within a cross) and 10 females (mean \pm SE of individual males crossed with individual females, $\mathrm{n}=5$ replicates per cross)

no effect of larval rearing density on the survival of diploid-sired or triploid-sired larvae ( $p>0.05$ ). After first using ANCOVA to demonstrate that density could be eliminated as a covariate, a subsequent ANOVA revealed significant differences in daily larval survival between offspring from diploids and triploids $(\mathrm{p}<0.05)$. Based on arithmetic means, larval survival time to $100 \%$ mortality for diploids and triploids was $13.0 \pm 1.4$ and

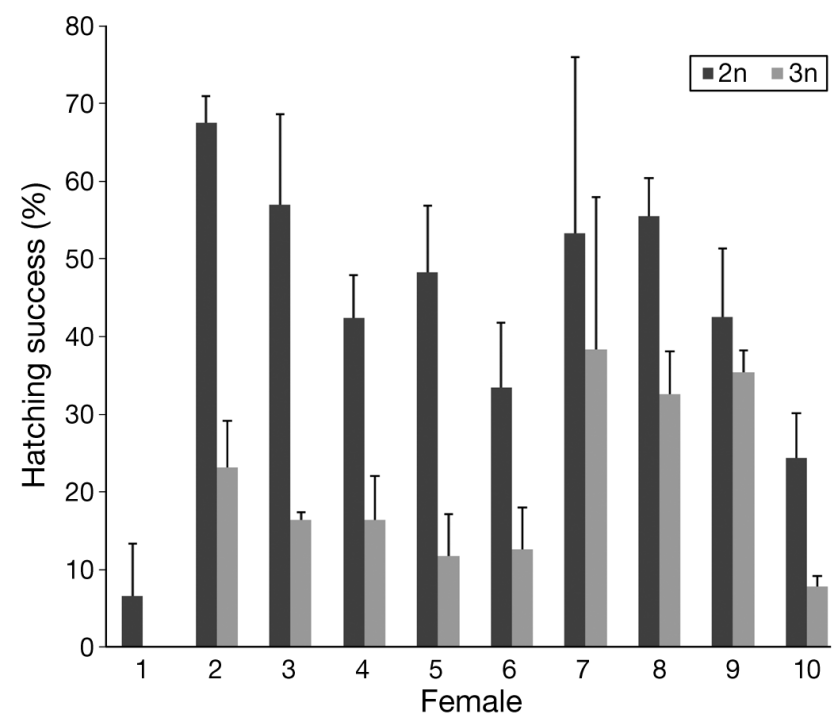

Fig. 2. Gadus morhua. Hatching success of progeny from eggs fertilized by milt from 10 pairs of diploid ( $2 n$ ) and triploid $(3 n)$ Atlantic cod siblings (mean \pm SE of individual males crossed with individual females, $\mathrm{n}=5$ replicates per cross). Eggs of Female 1 did not hatch when fertilized by the $3 \mathrm{n}$ male
$5.0 \pm 1.4 \mathrm{~d}$, respectively. Overall survivorship performance of triploid-sired larvae was inferior to that of their diploid counterparts (Fig. 3). Many of the offspring sired by triploids were malformed.

\section{Spermatozoan morphology and motility}

Spermatozoa sampled from 14 males revealed significant differences in milt from diploids and triploids in all parameters measured, with cells from triploids being larger, more elongated and more elliptical (Table 3). Spermatozoan motility analysis of 26 males revealed no significant interaction between sire ploidy and time $(p=0.720)$, and there was no effect of sire ploidy on spermatozoan motility at 20 and 40 s postactivation $(p=0.651)$. The mean VCLs $( \pm$ SE) for spermatozoa from diploids and triploids were $55.26 \pm 3.27$ and $55.97 \pm 2.94 \mu \mathrm{m} \mathrm{s}^{-1}$, respectively, at $20 \mathrm{~s}$ post-activation and $41.58 \pm 2.61$ and $44.08 \pm 3.23 \mu \mathrm{m} \mathrm{s}^{-1}$, respectively, at $40 \mathrm{~s}$ post-activation.

\section{DISCUSSION}

The utility of triploidy to improve culture production and reduce the risk of genetic introgression with wild fish has been explored for several fish species (Piferrer

Table 2. Gadus morhua. Number of embryos sired by diploid $(2 \mathrm{n})$ and triploid $(3 \mathrm{n})$ males of each spawning event (batch, all in 2008). A total of 16 spawning events were analyzed, with some trios having more than one event. The log-likelihood goodness of fit $G$-test was used to assess whether there was a significant difference in proportion of larvae sired by each male by batch ( $\mathrm{df}=1$ for each batch), and the heterogeneity $G$-test $\left(G_{H}\right)$ to assess whether individual trios were homogeneous in the proportion of larvae sired by each male among all batches (df for each trio in parentheses). ${ }^{*} \mathrm{p}<0.05{ }_{i}{ }^{* *} \mathrm{p}<$ $0.01 ;{ }^{* * *} \mathrm{p}<0.001$; na: not available

\begin{tabular}{|c|c|c|c|c|c|}
\hline Trio & Batch & $2 n$ & $3 n$ & $G$ & $G_{\mathrm{H}}$ \\
\hline 1 & Feb $\begin{array}{r}1 \\
11\end{array}$ & $\begin{array}{l}24 \\
19\end{array}$ & $\begin{array}{l}0 \\
0\end{array}$ & $\begin{array}{l}28.41^{* * *} \\
21.71^{* * *}\end{array}$ & $0(1)$ \\
\hline 2 & Feb 19 & 24 & 1 & $23.31^{* * *}$ & na \\
\hline 3 & $\begin{aligned} & \text { Mar } 2 \\
& 6 \\
& 12 \\
& 18\end{aligned}$ & $\begin{array}{c}2 \\
0 \\
0 \\
23\end{array}$ & $\begin{array}{c}11 \\
21 \\
6 \\
9\end{array}$ & $\begin{array}{c}5.29^{*} \\
24.39^{* * *} \\
4.88^{*} \\
27.07^{* * *}\end{array}$ & $73.47^{* * *}(3)$ \\
\hline 4 & Feb 21 & 0 & 14 & $24.39^{* * *}$ & na \\
\hline 5 & $\begin{aligned} & \text { Feb } 27 \\
& \text { Mar } 6 \\
& 10 \\
& 18 \\
& 24 \\
& 30\end{aligned}$ & $\begin{array}{l}0 \\
0 \\
5 \\
0 \\
0 \\
0\end{array}$ & $\begin{array}{l}14 \\
11 \\
30 \\
11 \\
11 \\
15\end{array}$ & $\begin{array}{l}15.09^{* * *} \\
11.18^{* * *} \\
18.08^{* * *} \\
11.18^{* * *} \\
11.18^{* * *} \\
16.41^{* * *}\end{array}$ & $10.68(5)$ \\
\hline 6 & $\begin{array}{r}\text { Mar } 9 \\
12\end{array}$ & $\begin{array}{l}9 \\
0\end{array}$ & $\begin{array}{l}22 \\
14\end{array}$ & $\begin{array}{c}4.77^{*} \\
15.09^{* * *}\end{array}$ & $7.68^{* *}(1)$ \\
\hline
\end{tabular}




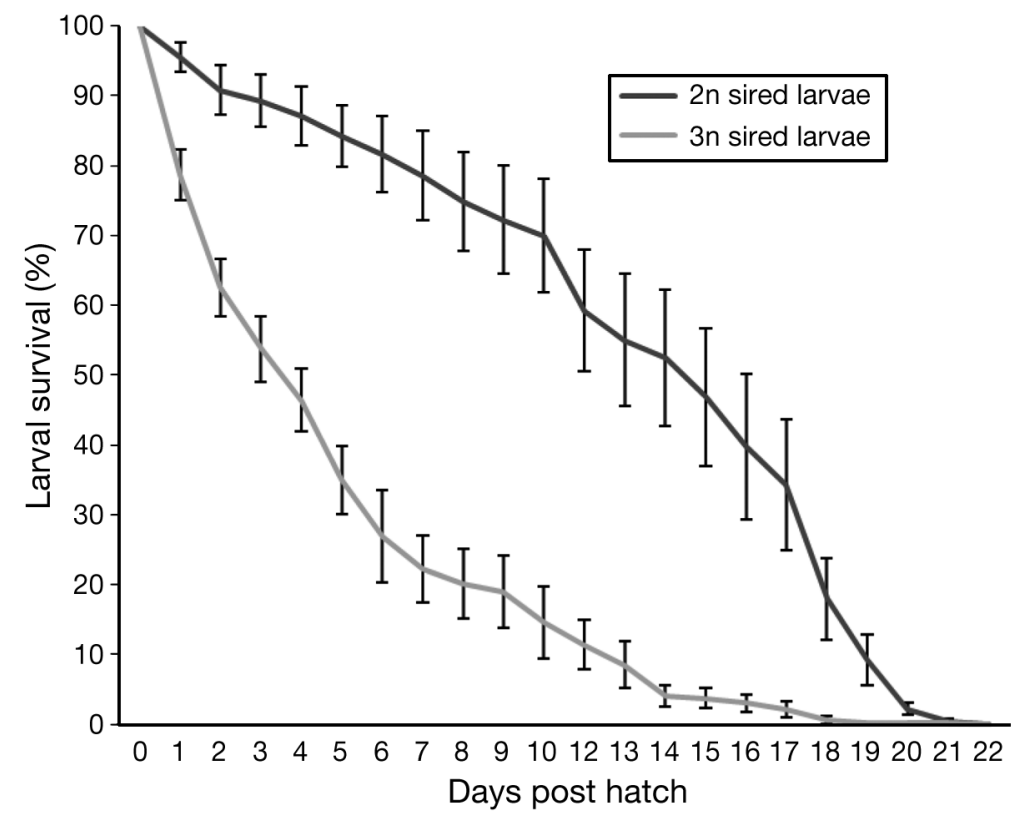

Fig. 3. Gadus morhua. Larval survival of progeny from eggs fertilized by milt from diploid (2n) and triploid (3n) Atlantic cod. Larval replicate data were pooled from all crosses and the mean $( \pm \mathrm{SE})$ percent daily survival calculated until $100 \%$ mortality

et al. 2009). Dramatic suppression of ovarian development by triploidy induction is commonly achieved, though development of the testes is often minimally affected (Benfey 1999, Piferrer et al. 2009). For Atlantic cod, we demonstrated that triploid males in competitive, size-matched mating with diploid males were successful at siring young and, although their spermatozoa were larger than those of diploids, they exhibited normal fertilizing potential in vitro.

When cod escape from sea cages, they have the potential to compete with native fish that form aggregations on natal spawning grounds which historically were of large size, such as those reported on a variety of banks in the Northwest Atlantic (Morgan \& Trippel 1996, Morgan et al. 1997). Behavioural observations (Hutchings et al. 1999, Bekkevold et al. 2002) have

Table 3. Gadus morhua. Spermatozoan morphological characteristics of diploid (2n) and triploid (3n) Atlantic cod (mean $\pm \mathrm{SE}$; $\mathrm{df}=11, \mathrm{n}=700$ spermatozoa per ploidy). See 'Materials and methods - spermatozoan morphology' for definition of parameters. 'Major' and 'Minor' are length and width, respectively

\begin{tabular}{|lccc|}
\hline Parameter & 2n & 3n & $\mathrm{p}$ \\
\hline Area $\left(\mu \mathrm{m}^{2}\right)$ & $4.82 \pm 0.27$ & $6.29 \pm 0.26$ & 0.003 \\
Perimeter $(\mu \mathrm{m})$ & $8.44 \pm 0.23$ & $9.79 \pm 0.23$ & 0.002 \\
Major $(\mu \mathrm{m})$ & $3.045 \pm 0.078$ & $3.600 \pm 0.091$ & 0.001 \\
Minor $(\mu \mathrm{m})$ & $2.005 \pm 0.065$ & $2.220 \pm 0.048$ & 0.022 \\
Elipticity & $1.530 \pm 0.019$ & $1.632 \pm 0.025$ & 0.008 \\
Elongation & $0.206 \pm 0.006$ & $0.236 \pm 0.008$ & 0.01 \\
\hline
\end{tabular}

suggested that cod display a lekking mating system (Nordeide \& Folstad 2000). Males dominate the spawning grounds, creating shoals which the females enter when ready to spawn (Morgan \& Trippel 1996, Robichaud \& Rose 2003). Within large aggregations comprised of adults forming hierarchical ranks, triploids may be at a disadvantage if they tend to exhibit submissive behaviour, as reported in several other species (reviewed by Benfey 1999). However, these earlier studies focused on feeding hierarchies; in the present study we did not undertake spawning behaviour observations, but since triploid males were successful in siring young, frequently of entire egg batches, presumably they were not acting in a submissive manner to diploids.

The nature and outcome of mating interactions may differ in arenas involving wild fish, as wild diploid Atlantic salmon males were noted to outcompete farmed males on experimental spawning redds (Weir et al. 2004). In a scenario where triploid cod escape and the males locate a native spawning assemblage, a number of obstacles remain to be overcome for them to successfully access wild females. Triploid males may be positioned at lower social ranks than native diploids, particularly relative to resident sires that have a previous spawning history and are dominantly aggressive. On spawning grounds, it has been shown that farmed cod reside higher in the water column than wild cod (Meager et al. 2009). Being kept at shallower depths and on the perimeter of the spawning shoals would reduce the probability of farmed males gaining access to ovulating females. This may be the case in larger offshore spawning grounds, but smaller inshore spawning grounds (Smedbol \& Wroblewski 1997) that have been severely depleted may present fewer obstacles for access to females, especially if a small resident group of wild males associated with a nearly extirpated assemblage were to be overwhelmed by a large number of escaped triploid males. A typical sea cage of triploid cod could contain $\sim 50000$ fish, and if $50 \%$ are males then a large fraction of escaped males attempting to court wild females in a spawning assemblage numbering in the hundreds to thousands could be triploids.

Additional males also participated as accessory sires with a male-female pair in captive gadoid breeding studies (Hutchings et al. 1999, Bekkevold et al. 2002, Trippel et al. 2009). Hence, although wild males may lead the intricate courtship behaviour of a spawning act and fertilize the majority of eggs released, the remainder could be sired by satellite or sneaker 
triploids. This may have been the case for our competitive spawning experiment where in each spawning event one male sired a significantly higher proportion of eggs while the subordinate male may have entered into the proximity of the spawning act of the 2 courting fish to release milt and fertilize a significantly lower amount of eggs. It is unknown to what degree relative spawning success of diploids and triploids would have varied if a greater number of fish were used in the competitive spawning experiments, since facilities and fish were limited to explore this scenario. If escaped triploid males highly outnumbered wild diploid males on a spawning ground, then it might be possible for triploids to sire a greater proportion of offspring by having numerous sneaker males join in a single spawning event. In research on haddock Melanogrammus aeglefinus in a communal tank holding 18 adults, it was shown that no more than 3 males participated in a spawning event with a single female, with 1 male fertilizing on average $73.9 \%$ of eggs (Trippel et al. 2009). Interestingly, triploids tended to be more successful in the free-spawning tanks (i.e. 12 of 16 egg batches and in 4 of 6 tanks), whereas there were no significant differences between male types in the in vitro tests. It is important to recognize that our competitive spawning experiment was conducted on only 6 trios with often unequal egg batch production per female. Hence the results should be treated with caution when interpreting them to reflect the relative spawning success of diploid and triploid males of this species. Specifically, the 2 tanks in which diploids dominated were in total only represented by 3 spawnings and the fourth diploid spawning act occurred in another tank in which the triploid dominated the other egg batches. A greater number of embryos could also have been used to ascertain relative spawning success for each egg batch; however, since males within a spawning trio were always full-sibs (i.e. brothers), some difficulty was occasionally experienced with the choice of genetic markers employed in the parentage analysis such that some of the selected $>20$ embryos could not be genotyped. Our selection of trios based on physical traits, however, proved to be well matched as body skewness has been shown to be problematic in other studies involving diploids and triploids (O'Keefe \& Benfey 1997) and our choice of full-sib males is believed to be unique among this type of study.

It has been shown that the majority of reared juvenile cod released from known areas may remain in close proximity $(<10 \mathrm{~km})$ of the release points (Svåsand \& Kristiansen 1990) and will follow similar migration patterns as wild cod, frequenting spawning grounds and remaining within inshore areas (Svåsand et al. 1990). It has also been shown that larger maturing escapees (length range $=50$ to $60 \mathrm{~cm}$ ) may disperse randomly away from the farms and frequent local spawning grounds (Uglem et al. 2008). Thus great potential exists for spawning interference if the escape event occurs near existing, inshore shoals of spawning cod. In Canada, cod culture is currently being explored in the Bay of Fundy area and the southern shore of Newfoundland, whereas in Norway, cod mariculture has been more widespread along the country's coastline which is characterized by numerous fjords that often possess local spawning grounds (Svåsand et al. 1990).

In Canada, tagged wild cod (mean length $=64 \mathrm{~cm}$ ) remained within $14 \mathrm{~km}$ of their release point, with movement within the Fundy Isles archipelago and slightly beyond (Brooking et al. 2006), supporting the theory of potential inshore populations near mariculture sites. It is also noteworthy that if triploid males were to escape and spawn with wild females, they would be displacing diploid males that would normally have fertilized a female's eggs and potentially contributed to future recruitment of wild stocks. Mating between triploid males and wild diploid females effectively reduces a female's fitness for that spawning event, but does ensure that any offspring sired by triploid aquaculture escapees will not survive (via production of aneuploids). In this manner the farming of triploids would not compromise the genetic integrity of wild stocks. In 2009, >50000 juvenile diploid cod of New Brunswick and New Hampshire origin were transferred to Newfoundland as part of the industry's plans to expand cod culture in Atlantic Canada and examine the relative merits of growing fish of nonlocal stocks. A similar practice of stocking cod of nonlocal origin has been employed along the Norwegian coast. Triploidy would have the potential to negate the possibility of viable embryo release and inter-breeding between escaped farmed fish with indigenous wild fish, yet permit utilization of non-local stocks with potentially higher growth potential.

Spermatozoan fertilizing ability is an important component of a male's reproductive potential (Trippel 2003, Butts et al. 2009). Previous studies have reported that male triploid Atlantic cod develop to a spawning state and produce functional spermatozoa capable of fertilizing eggs (Trippel et al. 2008, Peruzzi et al. 2009). The present study has extended these findings to reveal that no significant difference exists in the in vitro fertilization success of spermatozoa in relation to the sire's ploidy. The capacity of spermatozoa from triploids to fertilize eggs has also been shown in rainbow trout (Chourrout et al. 1986), grass carp Ctenopharyngodon idella (Van Eenennaam et al. 1990), yellowtail flounder Limanda ferruginea (Manning et al. 2004) and barfin flounder Verasper moseri (Mori et al. 2006). 
A decrease in ability of spermatozoa from tetraploid rainbow trout to fertilize eggs resulted from their heads being too large to enter the micropyle (Chourrout et al. 1986). The present study has also shown spermatozoan heads of triploid cod to be significantly larger (head width ranging from 1.6 to $2.9 \mu \mathrm{m}$ ) compared to diploids (width $=1.4$ to $2.6 \mu \mathrm{m}$ ), although they are still able to enter the micropyle (approximately $4.5 \mu \mathrm{m}$ in diameter at egg's surface; measurement made from Trippel 2003). Individual variation in the amount of genetic material among spermatozoa occurs for triploid fishes, ranging from haploid $(1 \mathrm{n})$ to diploid (2n), but predominantly aneuploid with an average of 1.5n (Allen et al. 1986, Benfey et al. 1986, Peruzzi et al. 2009).

It was expected that VCL would be slower for triploid cod due to greater drag created by their larger head size, but no such difference was found in relation to ploidy at 20 and $40 \mathrm{~s}$ post-activation. In a Norwegian study, spermatozoan VCL of triploid cod were significantly slower than that from diploids at 20 s postactivation but not at $40 \mathrm{~s}$ (based on 3 triploid males, on average $10.72 \mu \mathrm{m} \mathrm{s}^{-1}$ or $8.7 \%$ slower at $20 \mathrm{~s}$ postactivation; Peruzzi et al. 2009). We found the success of siring offspring by aneuploid spermatozoa from triploid males to be similar to those of their diploid counterparts, suggesting no apparent effect of spermatozoan head size or morphology on in vitro fertilization success. Spermatozoan motility of farmed male cod has been reported to be significantly lower than that of wild males (Skjæraasen et al. 2009, Butts et al. 2010) and thus mating success of farmed triploids based on spermatozoan swimming speed could be hampered when in competition with wild males. An interesting subsequent experiment would be to examine if cultivated triploid males would perform as well when in spawning competition with recently captured diploid males.

Offspring sired by artificially produced triploids are typically aneuploid and do not develop beyond embryonic or larval stages (Benfey 1999). This was shown in the present study and those of others (Manning et al. 2004, Peruzzi et al. 2009), thereby confirming triploid male sterility, i.e. an inability to produce viable offspring. If scientific researchers along with industry are searching for a method for the control of introgression of genes into the wild gene pool from selectively bred fish or those originating from the culture of non-local stocks, then triploidy is a suitable method for genetic containment. However, from the cod farmers' perspective, the application of triploidy is ineffective at suppressing male gonadal development. The use of allfemale triploid stocks should be considered as the next step towards the mariculture of this species, as it combines both environmental and industry goals towards sustainable aquaculture (Piferrer et al. 2009).
Acknowledgements. This research was funded by the DFO Aquaculture Collaborative Research and Development Program, in partnership with Cooke Aquaculture. The help of M. Barbeau, I. Butts, A. Garber, S. Fordham, S. Neil, S. Leadbeater, D. Martin-Robichaud, J. Power, S. Scouten, S. Taylor, A. Alonso Fernandez, L. Justason and C. Smith is gratefully acknowledged. The handling of fish was approved by DFO's Animal Care Committee, adhering to guidelines established by the Canadian Council on Animal Care.

\section{LITERATURE CITED}

Allen SK Jr (1983) Flow cytometry: assaying experimental polyploid fish and shellfish. Aquaculture 33:317-328

> Allen SK Jr, Thiery RG, Hagstrom NT (1986) Cytological evaluation of the likelihood that triploid grass carp will reproduce. Trans Am Fish Soc 115:841-848

Bekkevold D, Hansen MM, Loeschcke V (2002) Male reproductive competition in spawning aggregations of cod (Gadus morhua, L.). Mol Ecol 11:91-102

Bekkevold D, Hansen MM, Nielsen EE (2006) Genetic impact of gadoid culture on wild fish populations: predictions, lessons from salmonids, and possibilities for minimizing adverse effects. ICES J Mar Sci 63:198-208

Benfey TJ (1999) The physiology and behavior of triploid fishes. Rev Fish Sci 7:39-67

Benfey TJ, Solar II, de Jong G, Donaldson EM (1986) Flowcytometric confirmation of aneuploidy in sperm from triploid rainbow trout. Trans Am Fish Soc 115:838-840

Brooking P, Doucette G, Tinker S, Whoriskey FG (2006) Sonic tracking of wild cod, Gadus morhua, in an inshore region of the Bay of Fundy: a contribution to understanding the impact of cod farming for wild cod and endangered salmon populations. ICES J Mar Sci 63:1364-1371

> Butts IA, Trippel EA, Litvak MK (2009) The effect of sperm to egg ratio and gamete contact time on fertilization success in Atlantic cod Gadus morhua. Aquaculture 286:89-94

> Butts IAE, Litvak MK, Trippel EA (2010) Seasonal variations in seminal plasma and sperm characteristics of wildcaught and cultivated Atlantic cod Gadus morhua. Theriogenology 73:873-885

Cal RM, Vidal S, Gómez C, Álvarez-Blázquez B, Martínez P, Piferrer F (2006) Growth and gonadal development in diploid and triploid turbot (Scophthalmus maximus). Aquaculture 251:99-108

Carr JW, Anderson JM, Whoriskey FG, Dilworth T (1997) The occurrence and spawning of cultured Atlantic salmon (Salmo salar) in a Canadian river. ICES J Mar Sci 54: 1064-1073

Chourrout D, Chevassus B, Krieg F, Happe A, Burger G, Renard P (1986) Production of second generation triploid and tetraploid rainbow trout by mating tetraploid males and diploid females: potential of tetraploid fish. Theor Appl Genet 72:193-206

Crozier WW (1993) Evidence of genetic interaction between escaped farmed salmon and wild Atlantic salmon (Salmo salar L.) in a Northern Irish river. Aquaculture 113:19-29

> Hindar K, Fleming IA, McGinnity P, Diserud O (2006) Genetic and ecological effects of salmon farming on wild salmon: modelling from experimental results. ICES J Mar Sci 63: $1234-1247$

Hutchings JA, Fraser DJ (2008) The nature of fisheries- and farming-induced evolution. Mol Ecol 17:294-313

Hutchings JA, Bishop TD, McGregor-Shaw CR (1999) Spawning behaviour of Atlantic cod, Gadus morhua: evidence of mate competition and mate choice in a broadcast spawner. 
Can J Fish Aquat Sci 56:97-104

Jakobsdóttir B, Jörundsdóttir PD, Skírnisdóttir S, Hjörleifsdóttir S, Hreggviðsson GÓ, Daníelsdóttir K, Pampoulie C (2006) Nine new polymorphic microsatellite loci for the amplification of archived otolith DNA of Atlantic cod, Gadus morhua L. Mol Ecol Notes 6:337-339

> Jørstad KE, Van Der Meeren T, Paulsen OI, Thomsen T, Thorsen A, Svåsand T (2008) 'Escapes' of eggs from farmed cod spawning in net pens: recruitment to wild stocks. Rev Fish Sci 16:285-295

Manning AJ, Burton MPM, Crim LW (2004) Reproductive evaluation of triploid yellowtail flounder, Limanda ferruginea (Storer). Aquaculture 242:625-640

> Meager JJ, Skjæraasen JE, Fernö A, Karlsen Ø, Løkkeborg S, Michalsen K, Utskot SO (2009) Vertical dynamics and reproductive behaviour of farmed and wild Atlantic cod Gadus morhua. Mar Ecol Prog Ser 389:233-243

Miller KM, Le KD, Beacham TD (2000) Development of triand tetranucleotide repeat microsatellite loci in Atlantic cod (Gadus morhua). Mol Ecol 9:238-239

> Moe H, Dempster T, Sunde LM, Winther U, Fredheim A (2007) Technological solutions and operational measures to prevent escapes of Atlantic cod (Gadus morhua) from sea cages. Aquacult Res 38:91-99

> Moe H, Gaarder RH, Olsen A, Hopperstad OS (2009) Resistance of aquaculture net cage materials to biting by Atlantic cod (Gadus morhua). Aquac Eng 40:126-134

Morgan MJ, Trippel EA (1996) Skewed sex ratios in spawning shoals of Atlantic cod (Gadus morhua). ICES J Mar Sci 53:820-826

Morgan MJ, DeBlois M, Rose GA (1997) An observation on the reaction of Atlantic cod (Gadus morhua) in a spawning shoal to bottom trawling. Can J Fish Aquat Sci 54 (Suppl 1):217-223

Mori T, Saito S, Kishioka C, Arai K (2006) Aquaculture performance of triploid barfin flounder Verasper moseri. Fish Sci 72:270-277

Nordeide JT, Folstad I (2000) Is cod lekking or a promiscuous group spawner? Fish Fish 1:90-93

O'Keefe RA, Benfey TJ (1997) The feeding response of diploid and triploid Atlantic salmon and brook trout. J Fish Biol 51:989-997

O'Reilly PT, Canino MF, Bailey KM, Bentzen P (2000) Isolation of twenty low stutter di- and tetranucleotide microsatellites for population analyses of walleye pollock and other gadoids. J Fish Biol 56:1074-1086

- Peruzzi S, Rudolfsen G, Primicerio R, Frantzen M, Kaurić G (2009) Milt characteristics of diploid and triploid Atlantic cod (Gadus morhua L.). Aquac Res 40:1160-1169

Piferrer F, Beaumont A, Falguiere JC, Flajshans M, Haffray P, Colombo L (2009) Polyploid fish and shellfish: production, biology and applications to aquaculture for performance improvement and genetic containment. Aquaculture 293: 125-156

> Probst WN, Kraus G, Rideout RM, Trippel EA (2006) Parental effects on early life history traits of haddock Melanogrammus aeglefinus. ICES J Mar Sci 63:224-234

Rakitin A, Ferguson MM, Trippel EA (1999) Spermatocrit and spermatozoa density in Atlantic cod (Gadus morhua): correlation and variation during the spawning season. Aquaculture 170:349-358

Rakitin A, Ferguson MM, Trippel EA (2001) Male reproductive success and body size in Atlantic cod Gadus morhua L. Mar Biol 138:1077-1085

Editorial responsibility: Tim Dempster,

Trondheim, Norway
Robichaud D, Rose GA (2003) Sex differences in residency on a spawning ground. Fish Res 60:33-43

Rouxel C, Suquet M, Cosson J, Severe A, Quemener L, Fauvel C (2008) Changes in Atlantic cod (Gadus morhua L.) sperm quality during the spawning season. Aquac Res 39: 434-440

Skjæraasen JE, Mayer I, Meager JJ, Rudolfsen G, Karlsen Ø, Haugland T, Kleven O (2009) Sperm characteristics and competitive ability in farmed and wild cod. Mar Ecol Prog Ser 375:219-228

Smedbol RK, Wroblewski JS (1997) Evidence for inshore spawning of northern Atlantic cod (Gadus morhua) in Trinity Bay, Newfoundland, 1991-1993. Can J Fish Aquat Sci 54(Suppl 1):177-186

Sokal RR, Rohlf FJ (1995) Biometry. W. H. Freeman, New York Svåsand T, Kristiansen TS (1990) Enhancement studies of coastal cod in western Norway. II. Migration of reared coastal cod. ICES J Mar Sci 47:13-22

Svåsand T, Jørstad KE, Kristiansen TS (1990) Enhancement studies of coastal cod in western Norway. I. Recruitment of wild and reared cod to a local spawning stock. ICES J Mar Sci 47:5-12

Taranger GL, Carrillo M, Schulz RW, Fontaine P and others (2010) Control of puberty in farmed fish. Gen Comp Endocrinol 165:483-515

Thorsen A, Trippel EA, Lambert Y (2003) Experimental methods to monitor the production and quality of eggs of captive marine fish. J Northwest Atl Fish Sci 33:55-70

> Trippel EA (2003) Estimation of male reproductive success of marine fishes. J Northwest Atl Fish Sci 33:81-113

Trippel EA, Benfey TJ, Neil SR, Cross N, Blanchard MJ, Powell F (2008) Effects of continuous light and triploidy on growth and sexual maturation in Atlantic cod, Gadus morhua. Cybium 32(Suppl):136-138

Trippel EA, Rideout RM, O'Reilly OT, Herbinger CM, Neil SRE, Hamilton L (2009) Communal spawning leads to high potential for inbreeding in gadoid aquaculture. Aquaculture 296:27-35

> Tuset VM, Trippel EA, de Monserrat J (2008) Sperm morphology and its influence on swimming speed in Atlantic cod. J Appl Ichthyology 24:398-405

Uglem I, Bjørn PA, Dale T, Kerwath S and others (2008) Movements and spatiotemporal distribution of escaped farmed and local wild Atlantic cod (Gadus morhua L.). Aquac Res 39:158-170

Utter F (1998) Genetic problems of hatchery-reared progeny released into the wild, and how to deal with them. Bull Mar Sci 62:623-640

Van Eenennaam JP, Stocker RK, Thiery RG, Hagstrom TN, Doroshov SI (1990) Egg fertility, early development and survival from crosses of diploid female $\times$ triploid male grass carp (Ctenopharyngodon idella). Aquaculture 86:111-125

Webb JH, Hay DW, Cunningham PD, Youngson AF (1991) The spawning behaviour of escaped farmed and wild adult Atlantic salmon (Salmo salar L.) in a northern Scottish river. Aquaculture 98:97-110

> Weir LK, Hutchings JA, Fleming IA, Einum S (2004) Dominance relationships and behavioural correlates of individual spawning success in farmed and wild male Atlantic salmon, Salmo salar. J Anim Ecol 73:1069-1079

> Youngson AF, Dosdat A, Saroglia M, Jordan WC (2001) Genetic interactions between marine finfish in European aquaculture and wild conspecifics. J Appl Ichthyology 17: 153-162

Submitted: March 15, 2010; Accepted: June 29, 2010

Proofs received from author(s): July 14, 2010 